\title{
Biostratigraphy and Paleoecological Study of Pabdeh Formation in Interior Fars, Zagros Basin, Iran
}

\author{
Manooseh P. Khavari Khorassani ${ }^{1}$, Fatemeh Hadavi' ${ }^{1}$ Ebrahim Ghasemi-Nejad ${ }^{2}$, \\ Reza Mousavi-Harami ${ }^{1}$ \\ ${ }^{1}$ Departement of Geology, Faculty of Science, Ferdowsi University of Mashhad, Mashhad, Iran \\ ${ }^{2}$ Department of Geology, Faculty of Sciences, University of Tehran, Tehran, Iran \\ Email: mpkhavari@gmail.com, hadavi231@yahoo.com, eghaseminejad@gmail.com, harami2004@yahoo.com
}

Received 21 September 2014; revised 18 October 2014; accepted 12 November 2014

Copyright (C) 2014 by authors and Scientific Research Publishing Inc.

This work is licensed under the Creative Commons Attribution International License (CC BY).

http://creativecommons.org/licenses/by/4.0/

(c) (i) Open Access

\section{Abstract}

The Zagros basin, which trends NW-SE, is covered by a sea during the Paleogene, resulting in deposition of the Pabdeh Formation in the deeper parts of the basin. The thickness of the Pabdeh Formation in Tang-e-Abolhayat is about $221 \mathrm{~m}$ and it consists of purple shale at the base, gray shale, marl and marly limestone with a few horizons of nodular limestone toward the top. Seventytwo samples were collected and processed for nannofossil studies. Based on the identified nannofossil zones the age of the formation in Tang-e-Abolhayat is Late Paleocene-Late Oligocene (NP9NP24). Changes in the abundance of different genera over the studied interval have resulted in identification of three ecozones: Ecozone 1 is characterized by oligotrophic conditions with an abundance of warm water taxa; Ecozone 2 marks when conditions became more eutrophic and the abundance of temperate taxa increased; Ecozone 3 represents a return to oligotrophic conditions with an increase in warm water taxa.

\section{Keywords}

Biostratigraphy, Pabdeh Formation, Zagros, Ecozone, Nannofossil

\section{Introduction}

The Zagros Mountain belt, which trends NW-SE, extends over $1800 \mathrm{~km}$ from southeastern Turkey and north Iraq border in the NW and W Iran to the Makran area in the SE, where oceanic subduction is still active [1]. The Zagros Mountains are tectonically a part of the Alpine-Himalayan belt and formed as a result of convergence 
between Eurasia and remnants of Gondwana. The Zagros formed after collision between the Eurasian and Arabian plates, with closure of the Neo-Tethys Ocean in Late Cretaceous and later times [2] [3]. The Zagros region contains a large part of global thrust belt-related hydrocarbons, which are trapped in anticlinal structures. The Zagros fold-and-thrust belt is composed of two provinces (Lurestan and Fars), separated by the Dezful Embayment [2]-[5]. After Late Cretaceous movement, sea level rose and the Zagros basin was progressively inundated during the Paleogene, resulting in deposition of the Pabdeh Formation in deeper parts of the basin [6].

The Pabdeh Formation is recognized both in outcrop and the subsurface in Dezful Embayment and Izeh Zone, Fars and Lurestan in Iran. This formation, like other units in the Zagros basin, has been studied in most areas as a source rock for petroleum [7]. The studied section is located on Shiraz-Kazeron road along the Tang-e-Abolhayat ( $\left.29^{\circ} 42^{\prime} 17^{\prime \prime} \mathrm{N}, 51^{\circ} 57^{\prime} 26 " \mathrm{E}\right)$, with a thickness of about $221 \mathrm{~m}$, and consists of 18 lithological units as shown in Figure 1 and Figure 2: Unit 1 consists of $18.5 \mathrm{~m}$ of purple shale [8], overlain by $11.5 \mathrm{~m}$ of dark gray marl of Unit 2. Unit 3 is divided based on the occurrence of trace fossils in the marl over a 4.4-m interval. Unit 4 is characterized by $16 \mathrm{~m}$ of alternating marl and shale, which is overlain by $4 \mathrm{~m}$ of limestone assigned to Unit 5 . Unit 6 includes $10 \mathrm{~m}$ of shale and marl. Unit 7 contains $32.5 \mathrm{~m}$ of limy marl with interbedded shale, which is overlain by $23.5 \mathrm{~m}$ of gray to light brown marly limestone of Unit 8 . Unit 9 is identified by nodular limestone at the base with shale and marly limestone above, and is overlain by $10 \mathrm{~m}$ of gray limy shale of Unit 10 . Unit 11 is marked with $8.5 \mathrm{~m}$ of light gray limestone, which is overlain by $10 \mathrm{~m}$ dark shaly limestone of Unit 12 . Unit 13 is characterized by $10.5 \mathrm{~m}$ of thin-bedded light gray limestone and is overlain by $12.5 \mathrm{~m}$ light gray thick-bedded limestone of Unit 14 . Unit 15 consists of $9.5 \mathrm{~m}$ of light brown marly limestone, overlain by Units 16-18 that consist of thick $(8 \mathrm{~m})$, medium $(7.5 \mathrm{~m})$ and thin $(9.5 \mathrm{~m})$ bedded limestone, respectively.

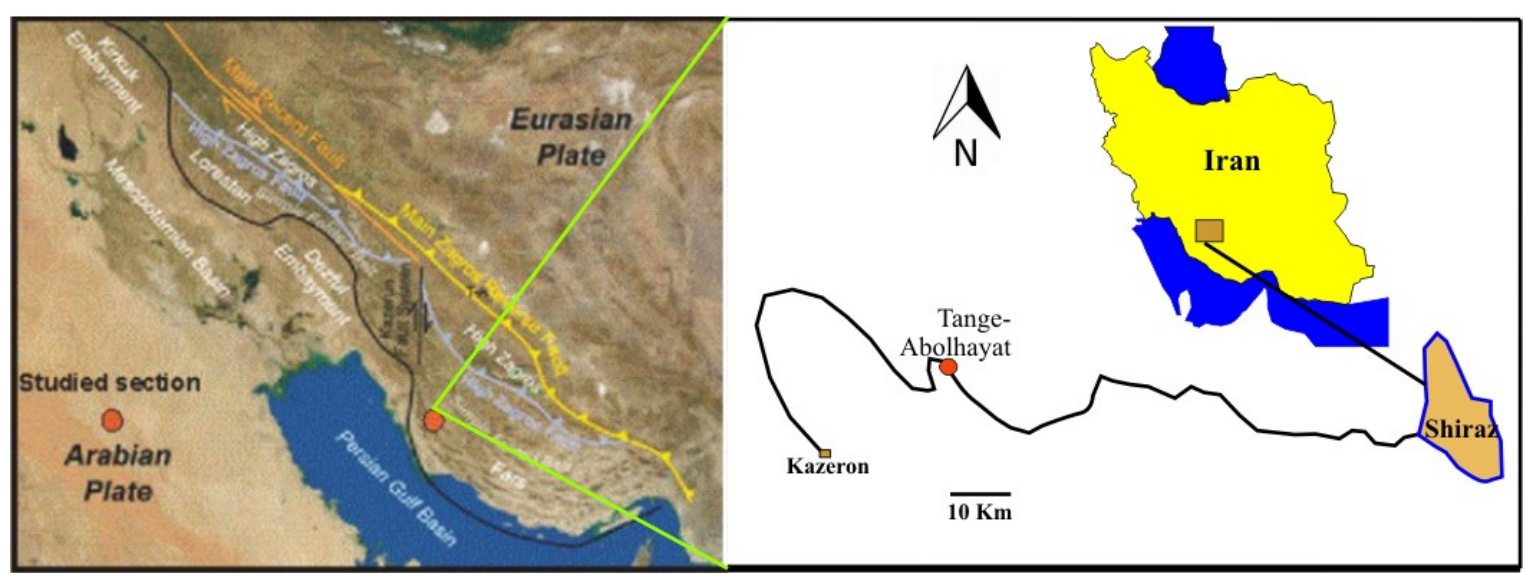

Figure1. Studied section in Fars Province Tang-e-Abolhayat.

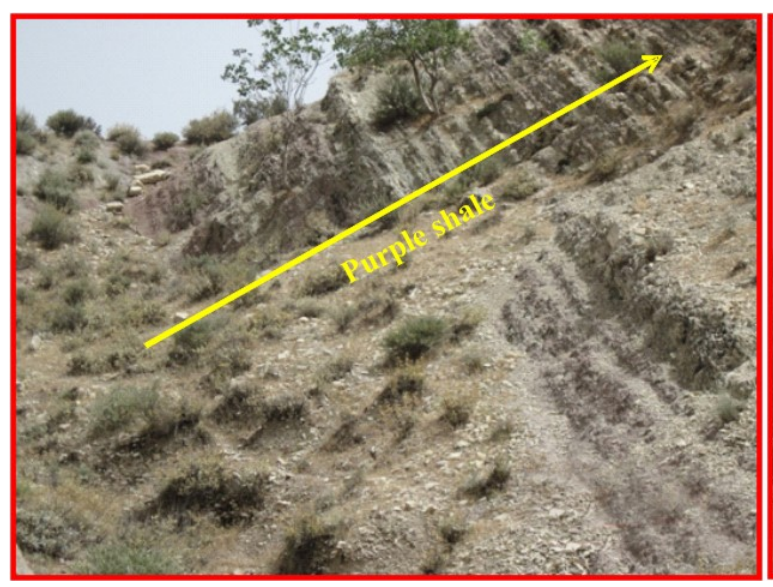

(a)

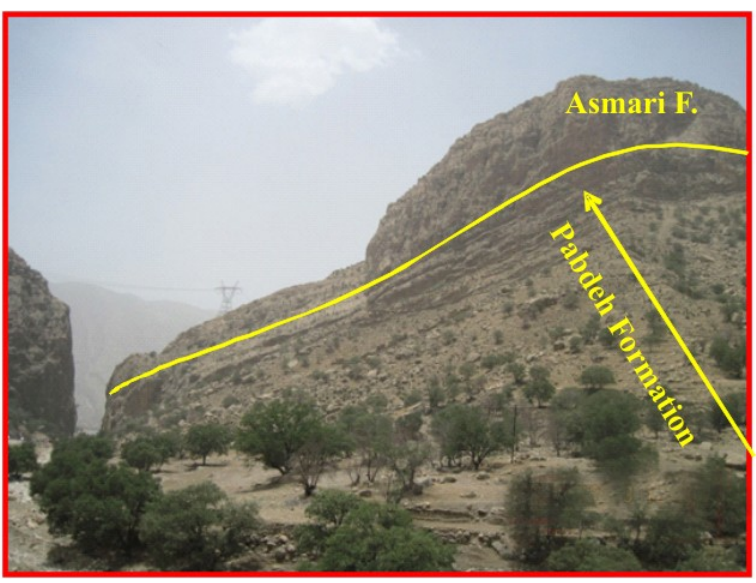

(b)

Figure 2. (a) Purple shale in the base; (b) Top of Pabdeh formation in Tang-e-Abolhayat. 
The aim of this study was to use calcareous nannofossil biostratigraphy to determine the age of this formation and identify paleoecological and paleoceanographic conditions during deposition based on nannoplankton assemblages. Coccoliths are tiny (micron-sized) calcite plates that form the covering of marine phytoplankton known as coccolithophores and when preserved as fossils are commonly referred to as calcareous nannofossils [9]. Coccoliths are abundant in seafloor sediments above the calcite compensation depth (CCD), and are usually transported to the seafloor in fecal pellets in marine snow. Their effect on deep-ocean $\mathrm{CO}_{2}$ budgets plays an important role in the global carbon cycle [9]. The ubiquitous nature of these algae, found in the photic zone in tropical to sub-polar waters, has credited them as one the largest producers of calcium carbonate in the open ocean today [10].

\section{Material and Methods}

Seventy-two samples were collected from fresh surfaces of outcrops for calcareous nannofossil studies based on lithological changes. We dug into the formation approximately $0.5 \mathrm{~m}$ before collecting each sample to ensure that fresh material was recovered.

Small amount of samples was used for studies of nannofossils. The standard smear-slide technique was used to prepare samples for light microscopy [11], which is one of the fastest methods used to prepare samples for micropaleontological investigations. No chemicals were used except for distilled water. Small amount of material scraped on to coverslip, drop of water added, mixed and smeared using a toothpick, dried on a hotplate, and the coverslip was attacehed with opaxi glu to the slide. Then the slides were studied with plane-polarized and cross-polarized light at $\times 1000$ magnification by Olympus B12 microscopy and using a gypsum plate when necessary. Species concepts are those described in Perch-Nielsen [12] and Bown [9] [13]. A count of 300 specimens for each sample was completed for paleoenvironmental analysis, with the collected data transformed to percent abundance.

The preparation technique for scanning electron microscope (SEM) study is that described by Donnally [14]: 0.5 $\mathrm{g}$ of sample was powdered and dissolved in $50 \mathrm{ml}$ of distilled water, and then placed for $30 \mathrm{~s}$ in an ultrasonic bath. The solution was then allowed to settle for $1 \mathrm{~min}$. The supernatant was removed and set aside for an hour, poured off, the residue diluted with distilled water, and one drop was dried on the filter for SEM examination. In this study, the biostratigraphic zonation is based primarily upon the calcareous nannofossil zonation of Martini [15] and secondarily upon the zonation of Okada and Bukry [16] and the timescale used is that of Gradstein et al. [17].

\section{Results}

The distribution of nannofossil taxa is shown in Figure 3 with selected species illustrated in Figure 4. Nannofossils are generally aboundant throughout the studied interval.

Preservation of calcareous nannofossils is moderate and specimens exhibit the effects of secondary alteration from etching and/or overgrowth. A total of 52 species were identified. The most common species are: Coccolithus pelagicus, Cyclicargolithus floridanus, Cyclicargolithus abisectus, Reticulofenestra dictyoda, Reticulofenestra bisecta, Sphenolithus radians, Sphenolithus moriformis and Zygrhablithus bijugatus.

\subsection{Biostratigraphy}

The studied section spans calcareous nannofossil Zones NP9-NP24 (late Paleocene to Oligocene) based on the distribution of species. We present the biostratigraphic results by zone below, first indicating how the zone is defined and then identifying which samples from the studied section are assigned to that zone. We describe the taxa used to identify the zone in our studied section, and also describe the general assemblage present in each zone.

Discoaster multiradiatus zone (NP9).

Definition: This zone extends from the first occurrence of Discoaster multiradiatus to the first occurrence of Tribrachiatus bramlettei (Bramlette \& Sullivan (1961) emend. Martini, 1971 and Bukry \& Bramlette, 1970).

Age: Late Paleocene (Thanetian).

Interval: Samples 1-5 (0 - $4.5 \mathrm{~m})$.

Comments: The marker for the top of this zone is absent from our studied material and so we therefore use secondary taxa to approximate the top of the zone. The last occurrence of Fasciculithus spp. is a lower NP10 event, occurring $\sim 220,000 \mathrm{k}$. y. after the evolution of $T$. bramlettei [17]. In addition, the first occurrence of $D$. 


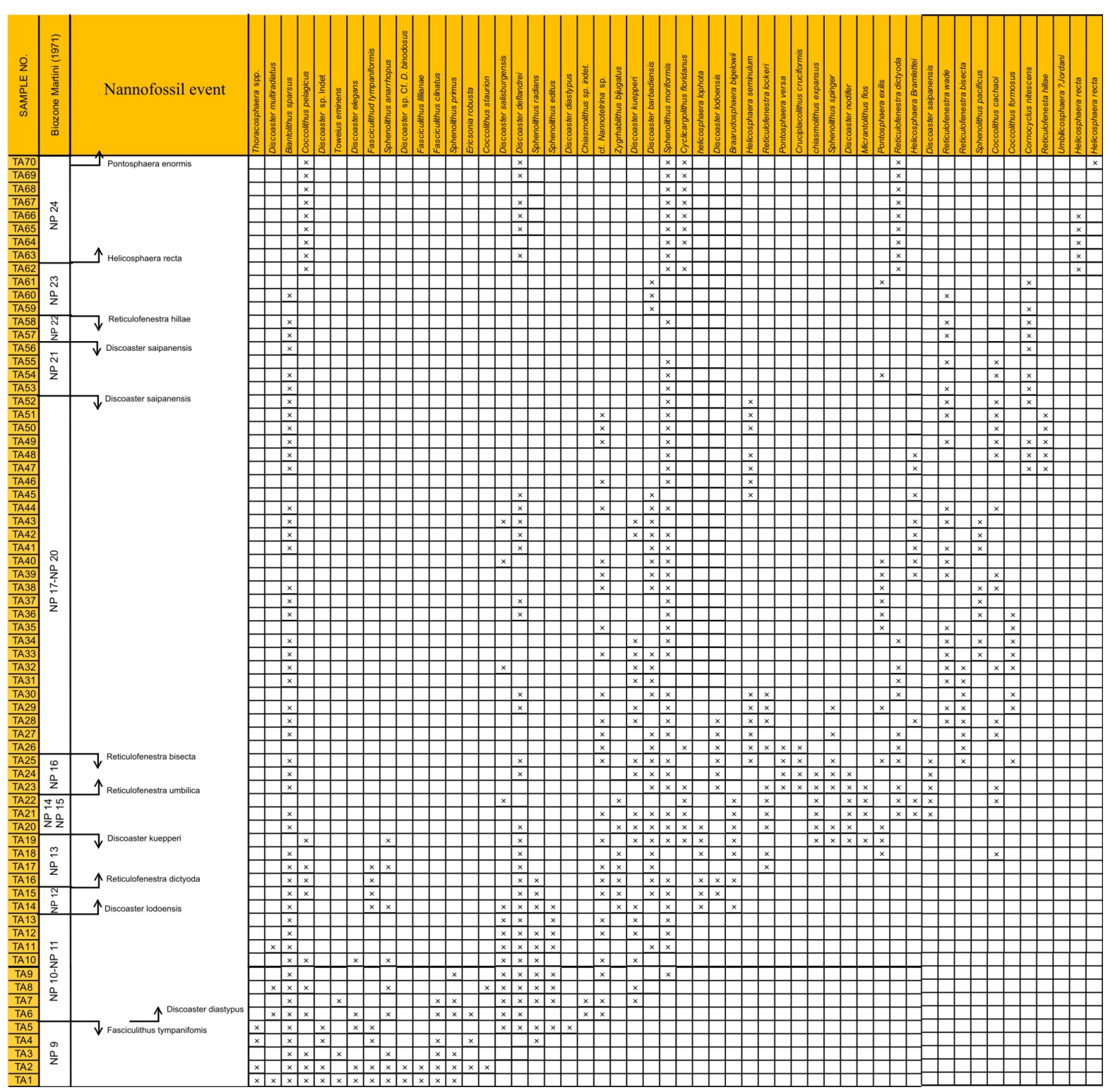

Figure 3. Calcareous nannofosils range chart and bioevent of Tang-e-Abolhayat section.

diastypus marks the base of Zone CP9 [16] and is an event that also occurs within Zone NP10.

The calcareous nannofossil assemblage of Zone NP9 is characterized by the presence of rare Fasciculithus spp., although $F$. tympaniformis is more abundant, Discoaster multiradiatus is common and the last occurrence of Toweius eminens is at the top of this zone.

Tribrachiatus contortus (NP10)/discoaster binodosus (NP11) zones.

Defintion: Zone NP10 is defined from the first occurrence of $T$. bramlettei to the last occurrence of Tribrachiatus contortus, and the top of Zone NP11 is defined by the first occurrence of Discoaster lodoensis (Hay, 1964; Mohler \& Hay, 1967).

Age: Early Eocene (Ypresian).

Interval: Samples 6-13 (4.5 - $11.5 \mathrm{~m})$.

Comments: Members of the Tribrachiatus lineage are absent in the study area and so the NP10/NP11 boundary could not be identified and thus these zones are combined.

These zones include the first occurrence of Discoaster diastypus, which falls within mid-NP10. Coccolithus pelagicus is abundant and Zygrhablithus bijugatus and Sphenolithus moriformis are common in this interval. 

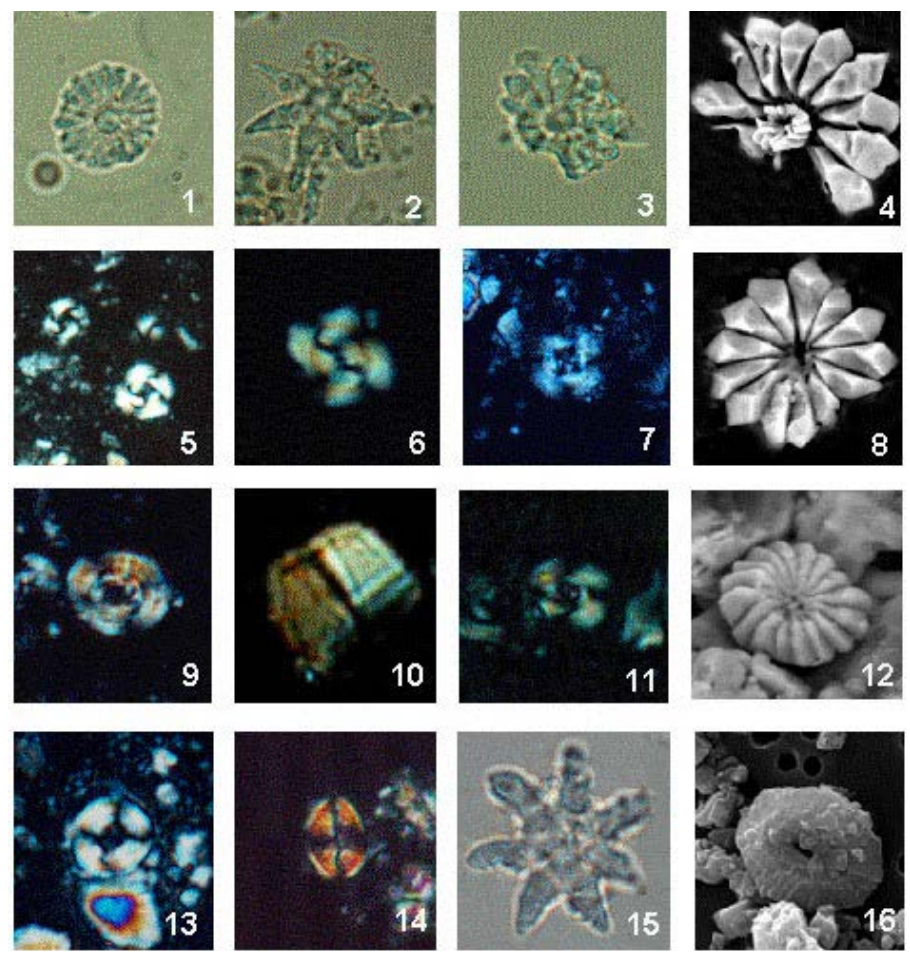

Figure 4. All figures in LM micrographs, cross nicol. 1000× and SEM micrograph 10000×. 1. Discoaster multiradiatus Bramlette and Riedel 1954; 2. Discoaster lodoensis Bramlette and Riedel 1954; 3. Discoaster diastypus Bramlette and Sullivan 1961; 4, 8. Discoaster barbadiensis Tan, 1927; 5. Reticulofenestra dictyoda, 6. Reticulofenestra bisecta (Hay, Mohler and Wade 1966) Roth 1970; 7. Reticulofenestra reticulata (Gartner and Smith 1967) Roth and Thierstein 1972; 9. Reticulofenestra hillae Bukry and Percival 1971; 10. Fasciculithus tympaniformis Hay \& Mohler in Hay et al., 1967; 11. Cribrocentrum reticulatum (Gartner and Smith 1967) Perch-Nielsen 1971; 12. Discoaster wemmelensis Achuthan and Stradner, 1969; 13. Ericsonia formosa (Kamptner, 1963) Haq, 1971; 14. Pontosphaera enormis (Locker 1967) Perch-Nielsen 1984; 15. Discoaster saipanensis Bramlette and Riedel 1954; 16. Coccolithus pelagicus (Wallich 1877) Schiller, 1930.

The first occurrences of Sphenolithus editus, S. radians and Discoaster barbadiensis also occur within these zones.

Tribrachiatus orthostylus zone (NP12).

Definition: This zone extends from the first occurrence Discoaster lodoensis to the last occurrence Tribrachiatus orthostylus (Brönnimann \& Stradner, 1960; Bukry, 1973).

Age: Early Eocene (Ypresian).

Interval: Samples 14-15 (11.5 - $17.5 \mathrm{~m})$.

Comments: Tribrachiatus orthostylus, whose extinction marks the top of this zone, is absent from the study area; however, the first appearance of Reticulofenestra dictyoda occurs at approximately the same time [17] and can therefore be used a secondary marker for the NP12/13 boundary. Discoaster spp. are common. Discoaster diastypus disappears near the top of this zone. This interval includes some reworking, as Fasciculithus tympaniformis is present in these samples.

Discoaster lodoensis (NP13)/discoaster sublodoensis (NP14) zones.

Definition: Zone NP13 extends from the last occurrence of Tribrachiatus orthostylus to the first occurrence of Discoaster sublodoensis, and the top of Zone NP14 is marked by the first occurrence of Nannotetrina fulgens (Brönnimann \& Stradner, 1960; Bukry, 1973/Hay, 1964; Bukry, 1973).

Age: Early Eocene (Ypresian).

Interval: Samples 16-20 (17.5 - $29 \mathrm{~m})$.

Comments: As mentioned above, the first appearance of Reticulofenestra is used to approximate the base of Zone NP13, since T. orthostylus is absent from the study area. Discoaster sublodoensis is also not found, and therefore Zones NP13 and NP14 are combined. The last occurrence of $D$. lodoensis occurs near the top of Zone 
NP14 [17] and is therefore used to approximate the NP14/NP15 boundary, since possible Nannotetrina specimens could not be reliably identified. This interval is characterized by common Discoaster spp. and abundant Coccolithus pelagicus and Sphenolithus radians. The first occurrence of Helicosphaera seminulum falls within this zone. The first occurrences of Pontosphaera versa, P. exilis, Sphenolithus spiniger, Discoater nodifer, and Chiasmolithus expansus and the last occurrence of $D$. kuepperi occur within this interval.

Nannotetrina fulgens zone (NP15).

Definition: Zone NP15 is defined from the first occurrence of Nannotetrina fulgens to the last occurrence of Blackites gladius (Hay (1967), emend Martini, 1970 and Bukry, 1973).

Age: Middle Eocene.

Interval: Samples 21-22 (29 - $34.5 \mathrm{~m})$.

Comments: Neither of the zonal markers occurs in the study area, so this zone is approximated using other taxa. The last occurrence of $D$. lodoensis is used to approximate the base of the zone. The first occurrence of $R$. umbilicus occurs within the lower part of overlying Zone NP16 and so the first occurrence of this taxon is used to indicate Zone NP16 in the study area. Cyclicargolithus floridanus, Sphenolithus radians, Discoaster barbadiensis, and $D$. saipanensis dominate the assemblage. Reticulofenestra wadeae is common.

Discoaster tanii nodifer zone (NP16).

Definition: This zone extends from the last occurrence of Blackites gladius to the last occurrence Chiasmolithus solitus (Hay (1967) emend. Martini, 1970).

Age: Middle Eocene.

Interval: Samples 23-25 (34.5 - $47.5 \mathrm{~m})$.

Comments: The base of this zone is approximated by the first occurrence of $R$. umbilicus, as B. gladius is absent in the study area. Thus, this zone corresponds to Subzone CP14a of Okada \& Bukry [16], which is defined from the first occurrence of $R$. umbilicus to the last occurrence of $C$. solitus. Reticulofenestra reticulata and Cruciplacolithus cruciformis first appear in this zone, and Reticulofenestra wadeae disappears. Cyclicargolithus floridanus, Coccolithus pelagicus and Discoaster barbadiensis are common in the nannofossil assemblage.

Discoaster saipanensis (NP17) to Sphenolithus psuedoradians zones (NP20).

Definition: Zone NP17 is defined from the last occurrence of Chiasmolithus solitus to the first occurrence of Chiasmolithus oamaruensis. The top of Zone NP18 is defined by the first occurrence of Isthmolithus recurvus. The top of Zone NP19 is defined by the first occurrence of Sphenolithus pseudoradians [15], but this taxon has a restricted distribution and has been identified in older Eocene sections [12] and so it is not reliable. Thus, Aubry [18] proposed a combined NP19/20 Zone that is defined from the first occurrence of I. recurvus to the last occurrence of Discoaster saipanensis (Martini, 1970; Hay, Mohler \& Wade (1966), emend. Martini, 1970).

Age: Middle Eocene-Late Eocene.

Interval: Samples 26-52 (47.5 - $156 \mathrm{~m})$.

Comments: Chiasmolithus oamaruensis and Isthmolithus recurvus are absent and so the zonal boundaries for the bases of Zones NP18 and NP19 could not be identified. Reticulofenestra reticulata is common throughout much of this interval and goes extinct near the top. Coccolithus pelagicus, Cyclicargolithus floridanus, Sphenolithus morformis, and Reticulofenestra bisecta dominate the nannofossil assemblage. Coccolithus formosus, Discoaster saipanensis, and Reticulofenetra spp. are common. Sphenolithus radians is common in the lower part of this interval, but decreases in abundance up-section and disappears near the top. Discoaster deflandrei is rare. Reticulofenestra hillae and Umbilicosphaera jordani first appear in the upper part of this interval.

Clasicoccus subdistichus zone (NP21).

Definition: This zone extends from the last occurrence of Discoaster saipanensis to the last occurrence of Coccolithus formosus (Roth \& Hay (1967), emend. Martini, 1970).

Age: Latest Eocene to Early Oligocene.

Interval: Samples 53-56 (156 - $187 \mathrm{~m})$.

Comments: The nannofossil assemblage is characterized by Cocolithus pelagicus, Cyclicargolithus floridanus, Reticulofenesta dictyoda, $R$. bisecta, and $R$. hillae. Discoaster spp. and Sphenolithus spp. are rare or absent.

Helicosphaera reticulata zone (NP22).

Definition: This zone extends from the last occurrence of Coccolithus fosmosus to the last occurrence of Reticulofenestra umbilicus (Martini, 1971).

Age: Early Oligocene. 
Interval: Samples 57-58 (187 - $194 \mathrm{~m})$.

Comments: In this study the top of zone is identified by the last occurrence of Reticulofenestra hillae, which is considered a junior synonym of $R$. umbilicus by some [19]. It is distinguished from $R$. umbilicus by its wide collar and narrow central aea. The nannofossil assemblage is similar to that of NP21.

Sphenolithus predistentus zone (NP23).

Definition: This zone extends from the last occurrence of Reticulofenestra umbilicus to the first occurrence of Sphenolithus ciperoensis (Martini, 1971).

Age: Early Oligocene.

Interval: Samples 59-62 (194 - $207.5 \mathrm{~m})$.

Comments: In this study the top of zone is approximated by the first occurrence of Helicosphaera recta, which is close to the first occurrence of Sphenolithus ciperoensis and thus can be used to approximate the NP23/ NP24 boundry [12]. The nannofossil assemblage is dominated by Coccolithus pelagicus, Sphenolithus moriformis, Cyclicargolithus floridanus, and Reticulofenestra dictyoda. The diversity in Oligocene compared with Eocene assemblages is clearly low.

Sphenolithus distentus zone (NP24).

Definition: This zone extends from the first occurrence of Sphenolithus ciperoensis to the last occurrence of Sphenolithus distentus (Martini, 1971).

Age: Late Oligocene.

Interval: Samples 63-70 (207.5 - $221 \mathrm{~m})$.

Comments: The top of this zone is approximated by the first occurrence of Pontosphaera enormis which has been shown to be a useful event for the Late Oligocene can approximate the NP24/NP25 boundary [19] [20]. Discoaster and Sphenolithus increase in abundance within this interval, and Cyclicargolithus floridanus, Reticulofenestra dictyoda and Helicosphaera recta are common.

\subsection{Paleoenvironment}

Changes in sea-surface temperature can induce changes in nannoplankton assemblage composition, which are then recorded in sediments [21]-[24]. Warm water taxa such as Discoaster, Fasciculithus and Sphenolithus [22] [26]-[29] are abundant in the lower part of the studied section. Temperate species such as Cyclicargolithus floridanus, Cyclicargolithus abisectus, and Reticulofenestra bisecta [30] are abundant in some parts of the section, and Reticulofenestra umbilicus is relatively common. Cold-water species such as Chiasmolithus, Isthmolithus recurvus, and Reticulofenestra daviesii [31] are rare or absent; however, Reticulofenestra lockeri is common. Three ecozones are identified based on changes in the percent abundance of different taxa with known paleoecological affinities.

Ecozone 1:

Interval: Samples 1 to 19 (27.5 m).

Zones: NP9 to NP13.

Age: Late Paleocene-Early Eocene.

Comments: This interval is characterized by higher abundances of warm water taxa, including Discoaster, Fasciculithus and Sphenolithus.

Ecozone 2:

Interval: Samples 20-62 (27.5 - $207.5 \mathrm{~m})$.

Zones: NP14-NP23.

Age: Middle Eocene-Early Oligocene.

Comments: This ecozone contains the species Cyclicargolithus abisectus. C. floridanus, and Coccolithus pelagicus which are considered oceanic forms that prefer mainly temperate waters [28] [32] are abundant. In this ecozone Reticulofenestra umbilicus, Zygrhablithus bijugatus and Braarudosphaera biglowii are also relatively common in lower part with Middle Eocene age.

Ecozone 3:

Interval: Samples 63-70 (207.5 - $221 \mathrm{~m})$, NP24.

Age: L. Oligocene.

Comments: The most abundant species of the calcareous nannofossils in this interval are Sphenolithus moriformis and Discoaster spp., which are warm water taxa and suggest a return to warmer conditions. 


\section{Discussion}

Nannofossil preservation is moderate. Biostratigraphic events are first occurrence and last occurrence, and as mentioned previously, the nannofossil zones used in this study refer to Martini [15] and Okada and Bukry, [16]. Eight zones and three combined zones is identified. Based on identified zones, the age of these sediments is Late Paleocene-Late Oligocene.

Calcareous nannoplankton are an excellent proxy for reconstruction of paleoecological conditions that result from paleoenvironmental change [33]. The presence and distribution of calcareous nannofossils depends on a number of factors, including temperature [30] [34] and nutrient availability [35] as well as ocean circulation and salinity [36]. Using nannofossils with known paleoecological preferences, we have divided the studied section into three ecozones:

Ecozone 1 is characterized by abundant Discoasters and Sphenolithus. These genera are associated with warm water, oligotrophic conditions [29]. Ecozone 1 spans nannofossil zones NP9 to NP13 (late Paleocene to early Eocene), which corresponds to a time of global warmth, including the Paleocene-Eocene Thermal Maximum and Early Eocoene Climatic Optimum. The Late Paleocene to Early Eocene spanned an interval when global oceanic deep waters warmed [37] and some studies suggest that the open ocean photic zones were characterized by oligotrophic conditions [22] [33] [38]. Discoaster, Fasciculithus and Sphenolithus were adapted to warmer, more oligotrophic environments [22] [27]-[30] [32] [39]. In the studied area increases in the abundance of Discoaster, Sphenolithus, and Fasciculithus suggest increased oligotrophic conditions in the surface water at that time. Although Discoaster and sphenolith diversity is low, species such as D. multiradiatus and S. moriformis are quite abundant through the upper Paleocene. The number and diversity of Discoaster species declined through the early Eocene and by the middle Eocene, only a few species of Discoaster remained in the region, and Discoaster multiradiatus, Discoaster diastypus, Fasciculithus spp. had gone extinct

Ecozone 2 is identified by abundant reticulofenestrids and Cyclicargolithus. The abundance of these genera suggest a change from oligotrophic to eutrophic conditions [34]. Ecozone 2 spans nannofossil Zones NP14NP23 (Middle Eocene to Early Oligocene) which corresponds to a long term cooling trend that occurred after the Early Eocene [39] [40]. In the studied section, the numbers of warm water, oligotrophic taxa decrease in abundance from the Middle toward the Late Eocene. The gradual disappearance of warm water nannofossil species during the Middle and Late Eocene and the occurrence of cold to temperate water species in the Late Eocene indicate progressive cooling through this interval time and show a change from oligotrophic to eutrophic conditions [33]. The early Oligocene is characterized as a time of great cooling, which is expressed in the calcareous nannofossil assemblage with an expansion of cold water placolith forms with larger sized coccoliths [12] [42]. Cyclicargolithus floridanus, Cyclicargolithus abisectus, Reticulofenetra dictyoda, R. wadeae, R. bisecta, and R. reticulata dominate the nannofossil assemblages. Zygrhablithus bijugatus and Coccolithus pelagicus are common, whereas warm water genera Discoaster and Sphenolithus are rare or absent during this time.

Ecozone 3 is marked by increase in the abundance of Discoaster and Sphenolithus, suggesting a return of warmer water. Ecozone 3 includes nannofossil zone NP24 and NP25 (Late Oligocene) The Late Oligocene was characterized by an increase in indicators of warm surface waters such as Discoaster and Sphenolithus [21] [40] [43]-[45]. The increased occurrences of the genera Sphenolithus, Helicosphaera and Pontosphaera could indicate near shore and warm water conditions, as the latter two genera appear to be more common in nearshore areas [46]. These changes correlate with global sea level curve (Figure 5).

\section{Conclusion}

The Pabdeh Formation in Tang-e-Abolhayat was deposited under open marine conditions and spans Zones NP9NP24 (late Paleocene to late Oligocene) based on nannofossil biostratigraphy. The section is divided into three ecozones based on changes in nannofossil assemblage that are correlated to changes in paleoenvironment. Ecozone 1 correlates to the upper Paleocene to upper Eocene interval and is characterized by a warm-water, oligotrophic assemblage. Lower abundances and diversity of middle Eocene Discoaster and Sphenolithus assemblages reflect a cooling trend of the surface waters that began after the Early Eocene. The overall nannofossil assemblage shows a change from oligotrophic to eutrophic conditions from the middle Eocene to the middle Oligocene (Ecozone 2). The Late Oligocene assemblages are characterized by an increase in warm-water, oligotrophic taxa (Ecozone 3). 

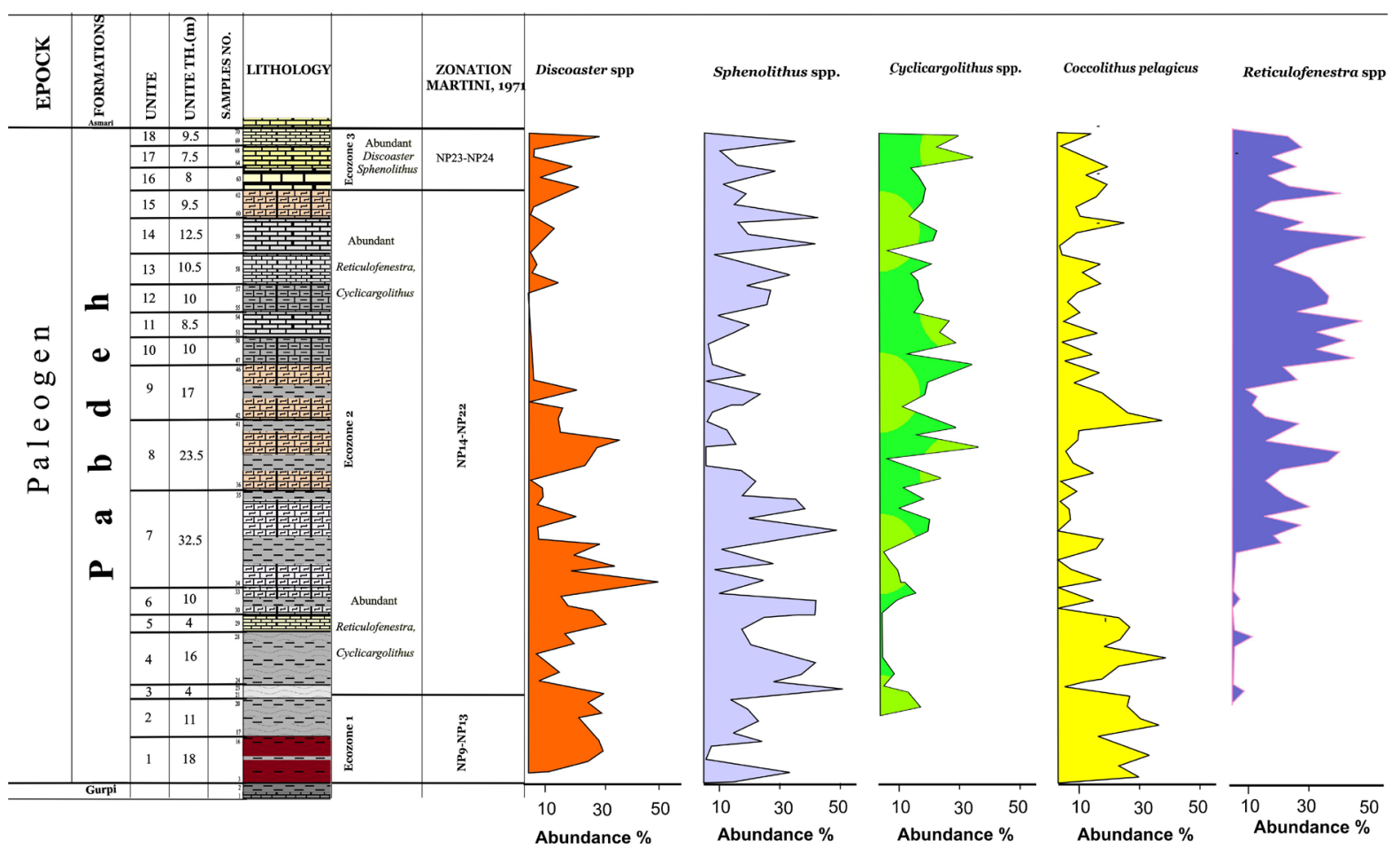

Figure 5. Abundances of selected taxa and ecozones at Tang-e-Abolhayt section.

\section{Acknowledgements}

We would like to thank Dr. Denise Kulhanek (Texas A\&M University) for her important guidance; Mehdi Badpa and Maysam Shafiee Ardestani (Ferdowsi University of Mashhad) for helping in the field.

\section{References}

[1] Smith, J., Burg, J.P., Dolati, A. and Sokoutis, D. (2010) Effects of Mass Waste Events on Thrust Wedges: Analogue Experiments and Application to the Makran Accretionary Wedge. Tectonics, 29, 1-11.

[2] Agard, P., Omrani, J., Jolivet, L. and Mouthereau, F. (2005) Convergence History across Zagros, Iran; Constraints from Collisional and Earlier Deformation. International Journal of Earth Sciences, 94, 401-419. http://dx.doi.org/10.1007/s00531-005-0481-4

[3] Alavi, M. (2004) Regional Stratigraphy of the Zagros Fold-Trust Belt of Iran and Its Proforland Evolution. American Journal Science, 304, 1-20. http://dx.doi.org/10.2475/ajs.304.1.1

[4] Farzipour-Saein, A., Yassaghi, A., Sherkati, S. and Koyi, H. (2009) Basin Evolution of the Lurestan Region in the Zagros Fold-and-Thrast Belt, Iran. Journal of Petroleum Geology, 32, 5-19. http://dx.doi.org/10.1111/j.1747-5457.2009.00432.x

[5] Lacome, O., Grasemann, B. and Simpson, G. (2011) Geodynamic Evolution of the Zagros. Geological Magazine, 148, 689-691. http://dx.doi.org/10.1017/S0016756811000550

[6] Sampo, M. (1969) Microfacies and Microfossils of the Zagrous Area Southwest Iran (From Pre-Permian to Miocene). NIOC, Iran.

[7] Kamali, M.R., Fathi Mobarakabad, A. and Mohsenian, E. (2006) Petroleum Geochemistry and Thermal Modeling of Pabdeh Formation in Dezful Embayment. Journal Science of University Tehran, 32, 1-11.

[8] James, G.A. and Wynd, J.G. (1965) Stratigraphical Nomenclature of Iranian Oil Consortium Agreement Area. American Association Petroleum Geology B, 49, 2182-2245.

[9] Bown, P.R. (1998) Calcareous Nannofossils Biostratigraphy. Kluwer Academic Press, Dordrecht. http://dx.doi.org/10.1007/978-94-011-4902-0

[10] Beaufort, L., Probert, I., de Garidel-Thoron, T., Bendif, E.M., Ruiz-Pino, D., Metzl, N., Goyet, C., Buchet, N., Coupel, P., Grelaud, M., Rost, B., Rickaby, R.E. and de Vargas, C. (2011) Sensitivity of Coccolithophores to Carbonate Che- 
mistry and Ocean Acidification. Nature, 476, 80-83. http://dx.doi.org/10.1038/nature10295

[11] Bown, P.R. and Young, J.R. (1998) Techniques. In: Bown, P.R., Ed., Calcareous Nannofossil Biostratigraphy, Paleoceanography, 1-3.

[12] Perch-Nielsen, K. (1985) Cenozoic Calcareous Nannofossils. In: Bolli, H.M., Sanders, J.B. and Perch-Nielsen, K., Eds., Plankton Stratigraphy, Cambridge University Press, Cambridge, 427-554.

[13] Bown, P.R. (2005) Paleogene Calcareous Nannofossils from the Kilwa and Lindi Areas of Coastal Tanzania (Tanzania Drilling Project 2003-4). Journal of Nannoplankton Research, 27, 21-95.

[14] Donnally, D.M. (1989) Calcareous Nannofossils of the Norwegian-Greenland Sea: ODP LEG 104. Proceedings of the Ocean Drilling Program, Scientific Results, 104, 458-486.

[15] Martini, M. (1971) Standard Tertiary and Quaternary Calcareous Nannoplankton Zonation. Proceeding of the 2nd Planktonic Conference Roma, 2, 739-785.

[16] Okada, H. and Bukry, D. (1980) Supplementary Modification and Introduction of Code Numbers to the Low-Latitude Coccolith Biostratigraphic Zonation (Bukry, 1973; 1975). Marine Micropaleontology, 5, 321-325. http://dx.doi.org/10.1016/0377-8398(80)90016-X

[17] Gradstein, F.M., Ogg, J.G., Schmitz, M. and Ogg, G. (2012) The Geologic Time Scale 2012. Elsevier Science BV, Oxford.

[18] Aubry, M.P. (1983) Correlations biostratigraphiques entre less formations plaeogenes epicontinentales de l'Europe du Nord-Ouest, basees sur la nannoplankton calcaire. Thesis, Universite Pierre et Marie Curie, Paris.

[19] Backman, J. and Hermelin, J.O.R. (1986) Morphometry of the Eocene Nannofossil Reticulofenestra umbilicus Lineage and Its Biochronological Consequences. Palaeogeography, Palaeoclimatology, Palaeoecology, 57, 103-116. http://dx.doi.org/10.1016/0031-0182(86)90009-X

[20] Martini, E. (1981) Nannoplankton in der Ober-Kreide, im Alttertiär und im tieferen Jungtertiär von Süddeutschland und dem angrenzenden Österreich. Geologica Bavarica, 82, 345-356.

[21] Melinte-Dobrinescu, M. and Brustur, T. (2008) Oligocene-Lower Miocene Events in Romania. Acta Palaeontologica, 6, 203-215.

[22] Tremolada, F. and Bralower, T.J. (2004) Nannofossils Assemblage Fluctuations during the Paleocene-Eocene Thermal Maximum at Site 213 (Indian Ocean) and 401 (North Atlantic Ocean): Paleoceanographic Implications. Marine Micropaleontology, 52, 107-116. http://dx.doi.org/10.1016/j.marmicro.2004.04.002

[23] Agnini, C., Fornaciari, E., Rio, D., Tateo, F., Backman, J. and Giusberti, L. (2006) Responses of Calcareous Nannofossil Assemblages, Mineralogy and Geochemistry to the Environmental Perturbations across the Paleocene/Eocene Boundary in the Venetian Pre-Alps. Marine Micropaleontology, 63, 19-38. http://dx.doi.org/10.1016/j.marmicro.2006.10.002

[24] Jiang, S. and Wise, S.W.J.R. (2009) Distinguishing the Influence of Digenesis on the Paleoecological Reconstruction of Nannoplankton across the Paleocene/Eocene Thermal Maximum: An Example from the Kerguelen Plateau, Southern Indian Ocean. Marine Micropaleontology, 72, 49-59. http://dx.doi.org/10.1016/j.marmicro.2009.03.003

[25] Bown, P.R. and Pearson, P. (2009) Calcareous Plankton Evolution and the Paleocene/Eocene Thermal Maximum Event: New Evidence from Tanzania. Marine Micropaleontology, 71, 60-70. http://dx.doi.org/10.1016/j.marmicro.2009.01.005

[26] Aubry, M.P. (1992) Paleogene Calcareous Nannofossils from the Kerguelen Plateau, Leg 120. In: Wise, S.W., Schlich, R., et al., Eds., Proceedings of the Ocean Drilling Program, Scientific Results, Ocean Drilling Program, College Station, 471-491.

[27] Flores, J., Sierro, F.J., Filippelli, M.A.B., Perez-Folgado, M., Vazquez, A. and Utrilla, R. (2005) Surface Water Dynamics and Phytoplankton Communities during Deposition of Cyclic Late Messinian Sapropel Sequences in the Western Mediterranean. Marine Micropaleontology, 56, 50-79. http://dx.doi.org/10.1016/j.marmicro.2005.04.002

[28] Villa, G. and Persico, D. (2006) Late Oligocene Climatic Changes: Evidence from Calcareous Nannofossils at Kerguelen Plateau Site 748 (Southern Ocean). Palaeogeography, Palaeoclimatology, Palaeoecology, 231, 110-119. http://dx.doi.org/10.1016/j.palaeo.2005.07.028

[29] Raffi, I., Backman, J., Zachos, J.C. and Sluijs, A. (2009) The Response of Calcareous Nannofossil Assemblages to the Paleoceene Eocene Thermal Maximum at the Walvis Ridge in the South Atlantic. Marine Micropaleontology, 70, 201212. http://dx.doi.org/10.1016/j.marmicro.2008.12.005

[30] Wie, W. and Wise Jr., S.W. (1990) Middle Eocene to Pleistocene Calcareous Nannofossils Recovered by Ocean Drilling Program Leg 113 in the Weddell Sea. Proceedings of the Ocean Drilling Program, Scientific Results, 113, 639666.

[31] Wie, W. and Thierstein, H.R. (1991) Upper Cretaceous and Cenozoic Calcareous Nannofossils of the Kerguelen Pla- 
teau (Southern Indian Ocean) and Prydz Bay (East Antarctica). Proceedings of the Ocean Drilling Program, Scientific Results, 119, 467-493.

[32] Haq, B.U. and Lohmann, G.P. (1976) Early Cenozoic Calcareous Nannoplankton Biogeography of the Atlantic Ocean. Marine Micropaleontology, 1, 119-194. http://dx.doi.org/10.1016/0377-8398(76)90008-6

[33] Gibbs, S.J., Bralower, T.J., Bown, P.R., Zachos, J.C. and Bybell, L.M. (2006) Shelf and Open-Ocean Clcareous Phytoplankton Assemblages across the Paleocene-Eocene Thermal Maximum: Implications for Global Productivity Gradients. Geology, 34, 233-236. http://dx.doi.org/10.1130/G22381.1

[34] Villa, G., Fioroni, C., Pea, L., Bohaty, S.M. and Persico, D. (2008) Middle Eocene-Late Oligocene Climate Variability: Calcareous Nannofossil Response at Kerguelen Plateau, Site 748. Marine Micropaleontology, 69, 173-192. http://dx.doi.org/10.1016/j.marmicro.2008.07.006

[35] Young, J.R. (1994) Functions of Coccoliths. In: Winter, A. and Siesser, W.G., Eds., Coccolithophores, Cambridge University Press, New York, 13-27.

[36] Aksu, A.E., Hiscott, R.N., Kaminski, M.A., Mudie, P.J., Gillespie, H., Abrajano, T. and Yaşar, D. (2002) Last GlacialHolocene Paleoceanography of the Black Sea and Marmara Sea: Stable Isotopic, Foraminiferal and Coccolith Evidence. Marine Geology, 190, 119-149. http://dx.doi.org/10.1016/S0025-3227(02)00345-6

[37] Speijer, R.P., Scheibner, C., Stadden, P. and Morsi, A.M.M. (2012) Response of Marine Ecosystems to Deep-Time Global Warming: A Synthesis of Biotic Patterns across the Paleocene-Eocene Thermal Maximum (PETM). Australian Journal of Earth Science, 105, 6-16.

[38] Tremolada, F., Erba, E. and Bralower, T.J. (2007) A Review of Calcareous Nannofossil Changes during the Early Aptian Oceanic Anoxic Event 1a and the Paleocene-Eocene Thermal Maximum: The Influence of Fertility, Temperature, and $\mathrm{pCO}_{2}$. Geology Society of American Special Papers, 424, 87-96.

[39] Bralower, T.J. (2002) Evidence of Surface Water Oligotrophy during the Paleocene-Eocene Thermal Maximum: Nannofossil Assemblage Data from Ocean Drilling Program Site 690 Maud Rise, Weddel Sea. Paleoceanography, 17, 1-12. http://dx.doi.org/10.1029/2001PA000662

[40] Zachos, J.C., Pagani, M., Sloan, L., Thomas, E. and Billups, K. (2001) Trends, Rhythms, and Aberrations in Global Climate 65 Ma to Present. Science, 292, 686-693. http://dx.doi.org/10.1126/science.1059412

[41] Zachos, J.C., Dickens, G.R. and Zeebe, R.E. (2008) An Early Cenozoic Perspective on Greenhouse Warming and Carbon Cycle Dynamics. Nature, 451, 279-283. http://dx.doi.org/10.1038/nature06588

[42] Blaj, T. (2009) Late Eocene through Oligocene Calcareous Nannofossils from the Palaeo-Equatorial Pacific Ocean Taxonomy, Preservation History, Biochronology and Evolution. Dissertation, Stockholm University, Stockholm.

[43] Bukry, D. (1973) Low-Latitude Coccolith Biostratigraphic Zonation. Initial Reports of the Deep Sea Drilling Project, 15, 685-703.

[44] Wei, W. and Wise Jr., S.W. (1989) Paleogene Calcareous Nannofossil Magnetobiochronology: Results from South Atlantic DSDP Site 516. Marine Micropaleontology, 14, 119-152. http://dx.doi.org/10.1016/0377-8398(89)90034-0

[45] De Man, E. and Van Simaeys, S. (2004) Late Oligocene Warming Event in the Southern Sea Basin: Benthic Foraminifera as Paleotemperature Proxies. Netherlands Journal of Geoscience, 83, 227-239.

[46] Ŝvábenická, L., Bubik, M. and Stránik, Z. (2007) Biostratigraphy and Paleoenvironmental Changes on the Transition from the Menilite to Krosno Lithofacies (Western Carpathians, Czech Republic). Geology Carpathians, 58, 327-262. 